\title{
Purulia Leper Home and Kindred Efforts on the Bengal-Bihar Frontier
}

\author{
E. Muir.
}

The Purulia Home, the largest of its kind in India, was founded by German missionaries many years before the war. It is now staffed by a Clerical Superintendent (a missionary of the C.M.S.), one European and one Indian doctor, and two nursing sisters. It is situated in the Manbhum district of Bihar in a healthy, dry (though warm) climate. The patients live in three-roomed cottages with four in each room. 
The male and female quarters are alongside of each other, separated by a wall. No married quarters are allowed. For leprous children there are hostels. There is separate accommodation for children under observation, i.e. in the intermediate stage between those with definite leprous lesions and those (children of lepers) who are free from all signs of the disease. The homes for the healthy children of lepers are a special feature. That for the girls is attached to the nursing sister's quarters, and that for the boys in the proximity of the superintendent's quarters.

Near the Home is an independent village composed of the healthy descendents of former inmates of the home. This is a flourishing village, and the good health of the inhabitants and their freedom from leprosy is a standing evidence against the old heredity theory of leprosy. The Home is supported by capitation grants from the Bihar Government and by grants from the Mission to Lepers. It is conducted on economical lines, the most of the work being done by the patients themselves. They build houses, cultivate the rice fields, and otherwise keep themselves healthy by occupational therapy.

A considerable amount of investigation into the nature of leprosy has been done in this institution especially in the last 15 years, the results being published in scientific journals. During 1936, 546 of the 795 in-patients received special treatment, as did also 1,243 out-patients.

The following statistics for the year give a rough idea of the extent and nature of the medical work:-

$$
\begin{array}{cc}
\text { In-patients. } & \text { Out-patients. } \\
\text { who received } & 456 \text { who were } \\
\text { upwards of } & \text { examined after } \\
3 \text { month's more than one } & \text { marts treatment. } \\
\text { treatment. } & \text { year's treats }
\end{array}
$$

$\begin{array}{llllr}\text { Much improved } \ldots & \ldots & \ldots & 6\end{array}$

Slightly improved $\quad \ldots \quad \ldots \quad 349$ 23

Total.

$\begin{array}{lllll}\text { Slightly improved } & \ldots & \cdots & 349 \\ \text { Worse } \quad \ldots \quad \cdots & \ldots & \ldots & 116\end{array}$

284

130

Left before disease arrested $\quad \ldots \quad 20$

267

Died

Disease arrested without deformities

Disease arrested with deformities

Hydnocreol Injections $\quad \ldots \quad \ldots \quad 19,789$

Surgical Dressings $\quad \ldots \quad \ldots \quad 57,322$

Bacteriological Examinations ... 2,903

Sedimentation Indices $\ldots \quad \ldots \quad 974$

974

$\begin{array}{lllrr}\text { Hookworm Examination } & \ldots & 1,011 \\ \text { Khan Tests } & \ldots & \ldots & \ldots & 136\end{array}$

Eye, Nose and Teeth Treatment 2,057 
Purulia is situated in an area of high leprosy endemicity in the bordering districts of Bengal and Bihar. Formerly this widespread area was forest land and inhabited by aboriginal tribes. The impact of the outside world has led to Hinduisation of most of the inhabitants, the majority of whom belong now to the lower Hindu castes. Aboriginals are free as a rule from leprosy, and the disease is not generally common among the people of the Gangetic plains. It is among the semi-aboriginals who are emerging from the simple tribal life into contact with the outside world that leprosy is most common, and hence the frequency of the disease in this area. Another reason is the geographic situation and the porous nature of the laterite soil, which make it a region of frequent famines; as a break in the continuity of the S.W. monsoons causes rapid dessication of the land and the ruin of the main crop of rice.

The Purulia Leper Home is the largest of several efforts to combat leprosy in this area. There are four other smaller institutions at Bankura, Raniganj, Deogarh and Saldoha, the latter two being in the Santhal Parganas. At Bankura there has been a strenuous educational scheme in the past few years, an account of which appears in the Report Section of this number.

Within this leprous area lie the richest coal mines of India, centering round Asansol and Dhanbaid. For several years strenuous efforts have been made by the Health Officer of the Asansol district to cope with leprosy, an Anti-leprosy Association being formed with a dozen branches, in connection with which several clinics have been begun, from which patients are followed up with a view to the voluntary segregation of all infectious cases. Similar work is now being developed in the Dhanbaid Mines area.

The chief danger of the spread of leprosy centres round industrial areas such as coal mines. In these are gathered together, away from the restraining influences of their own community: the ignorant and insanitary semi-aboriginal common labourer, the Sikh mechanic from the Punjab, and the high caste Hindu clerk and overseer. The last two categories are ignorant of the danger of acquiring contagion from the first, and they often fall victims to this surreptitious disease. The authorities are now awake to this danger which it is hoped will soon be brought under control. 